\title{
SOME MORPHOLOGICAL CHARACTERS OF FEMALE OF MOTHOCYA EPIMERICA COSTA, 1851 (FLABELLIFERA: CYMOTHOIDAE) FROM SEA OF MARMARA
}

\author{
Ali ALAS *, Ahmet ÖKTENER ** and Dilek TÜRKER ***
}

* Necmettin Erbakan University, A. K. Education Faculty, Department of Biology, B Block, Meram, Konya, Turkey TR-42090, alasali@hotmail.com

** Sheep Research Institute, Department of Fisheries, Çanakkale Street km 7, Bandirma, Balikesir, Turkey, TR-10200, ahmetoktener@yahoo.com

*** Balikesir University, Science Faculty, Department of Biology, Cagıs Campus, Balikesir, Turkey, TR-10300, dilekturkercakir@hotmail.com

DOI: 10.1515/trser-2015-0063

KEYWORDS: Mothocya, mandible, maxilliped, maxilla, maxillae.

ABSTRACT

Mothocya epimerica Costa, 1851 (Flabellifera: Cymothoidae) is a cymothoid parasite of fishes belonging to Atherinidae (Atherina hepsetus, Atherina boyeri) from Mediterranean Sea, Black Sea and Atlantic Ocean. Öktener and Sezgin (2000) recorded this parasite for the first time in Turkey. The mentioned authors presented some morphological characters, although, some characters are not explained in the publication. Some morphological characters seen on the mandible, maxilliped, maxilla, maxillue and the spines on pleopods of the female of $M$. epimerica are shown. The characters presented in our study are based on the drawings made from collected specimens.

RESUMEN: Algunas características morfológicas de hembras de Mothocya epimerica Costa, 1851 (Flabellifera, Cymothoidae) del Mar de Mármara.

Mothocya epimerica Costa, 1851 (Flabellifera: Cymothoidae) es un parasito de peces perteneciente a Atherinidae (Atherina hepsetus, Atherina boyeri) del Mar Mediterráneo, Mar Negro y Océano Atlántico. Öktener y Sezgin (2000) presentaron este parasito por primera vez procedente de Turquía. Ellos mostraron algunas características morfológicas, no obstante algunas características no están explicadas en la publicación. Algunas de las características vistas en la mandíbula, maxilípedos, maxilares, maxílulas, y las espinas sobre los pleópodos de hembras de $M$. epimerica son mostradas en este estudio. Dichas características están basadas en dibujos hechos a partir de especímenes recogidos.

REZUMAT: Caractere morfologice la femelele de Mothocya epimerica Costa, 1851 (Flabellifera: Cymothoidae) din Marea Marmara.

Mothocya epimerica Costa, 1851 (Flabellifera: Cymothoidae) este un parazit al peștilor din familia Atherinidae (Atherina hepsetus, Atherina boyeri) din Marea Mediterană, Marea Neagră şi Oceanul Atlantic. Öktener şi Sezgin (2000) au fost primii care au înregistrat acest parazit în Turcia. Autorii menționați au prezentat câteva caractere morfologice, dar unele caractere nu sunt explicate în articolul lor. În această lucrare, sunt prezentate câteva din caracterele morfologice pentru femela de $M$. epimerica observate pe mandibulă, maxiliped, maxilă, maxilulă şi pe spinii peopodelor. Caracterele prezentate în acest studiu sunt bazate pe desenele făcute pentru specimenele colectate. 


\section{INTRODUCTION}

Crustacean ectoparasites on marine fish are diverse. Many species of fish are parasitized by cymothoids (Crustacea, Isopoda, and Cymothoidae). These parasitic isopods are blood-feeding. Several species settle in the buccal cavity of fish, others live in the gill chamber or on the body surface including the fins (Brusca, 1981; Trilles, 1994).

The cymothoid fauna of Turkey has received no attention until a Ceratothoa sp. was reported from Boops boops (Linnaeus, 1758) (Perciformes: Sparidae) (Monod, 1931). Several years later, a number of studies have given some systematic records about several cymothoids parasitizing Turkish wild and cultured fishes (Kırkım, 1998; Tokşen, 1999; Öktener and Trilles, 2004; İnnal et al., 2007; Öktener et al., 2009; Kayis and Er, 2012).

The aim of the present study is to give some morphological characteristics of female Mothocya epimerica from the gill chamber of Atherina boyeri, to add more information on the descriptions given by Montalenti (1948), Trilles $(1968,1976)$ and Bruce (1986).

\section{MATERIAL AND METHODS}

The fish samples were collected by trawl and local gears from Bandirma Bay in 2014. The body surface, oral cavity and branchial chamber of each fish were examined for isopod parasites. The parasites were dislodged from their host and preserved directly in labelled tubes with $70 \%$ ethanol. The identification, scientific names and synonyms of parasite and host classification, were presented in Trilles (1968, 1976, 1994), Bruce (1986), Montalenti (1948), WoRMS Editorial Board (2014), Fricke et al. (2007) and, Froese and Pauly (2014). Drawings were performed using a stereomicroscope (Wild M5) with a camera lucida and a compound microscope (Olympus CH20). Measurements were taken in micrometres with a micrometric programme (Pro-way). Bruce (1986) was a consultant for terminology. Parasites (MNHN-IU2013-18750) were deposited in the collections of the Muséum National d'Histoire Naturelle (MNHN), Paris, France.

\section{RESULTS}

Mothocya epimerica was collected from the branchial chamber region of ten Atherina boyeri of among one hundred fifty specimens examined (prevalence $=6.6 \%$ ).

\section{Order Isopoda}

Family Cymothoidae Leach, 1814

Mothocya epimerica Costa, 1851

Syn. Mothocya epimerica Costa, in Hope, 1851

Ceratothoa atherinae Gourret, 1892

Livoneca sinuata Brian, 1912

Mothocya epiremica Brian, 1921

\section{Description of female.}

The body is slightly twisted to the right side, elongated, and about 2.8 times longer than wide (Figs. 1 and 2). The dorsum is weakly vaulted, the anterior margin of cephalon is slightly rounded, large eyes, 0.63 times width of cephalon, and the distance between them about $36 \%$ of head width. Pereon is about 0.65 as wide as long, pereonites one is longest and pereonite seven is shortest, posterolateral margins of pereonite seven is slightly rounded and produced in dorsal view. Pleon is about 0.4 as long as wide; all pleonites visible in dorsal view, but pleonite one is partially concealed by pereonite seven, pleonites two-five are entirely conspicuous in dorsal view, two-four subequal in length, and pleonite is five slightly longer and wider than the others. Pleotelson hemispherical is 0.66 times as long as wide and posterior margin rounded. 
Maxilla medial and lateral lobes each with two curved spines, medial lobe is covered with small spines (Figs. 6, 7 and 10A); maxillule with four terminal spines (Figs. 8 and 10B); maxilliped article three with four recurved spines (Figs. 4, 5 and 10C); mandible palp article three (Figs. 9 and 10D); Antennule with eight articles, generally extending to the middle of eye (Figs. 2 and 10E), antenna with eight articles, slender than antennule, not extending to anterior of pereonite one (Figs. 3 and 10F).

Pereopods almost similar, pereopod one is the longest, pereopod six is the shortest, and pereopod one is much longer than pereopod seven (Figs. 11A-G).

Pleopods with all rami lamellar, peduncles of pleopods with four hooks (Figs. 12A-E); endopod five with proximomedial lobe moderately developed.

Coxae conspicuous in dorsal view and posterior margins rounded; coxae two-six not produced beyond posterior of respective segments, coxae of pereonites seven extending slightly beyond posterior of segment (Figs. 13A-B). Uropod short, not extending beyond posterior margin of pleotelson, exopod slightly longer than endopod (Fig. 13C).

White or brown in alcohol, densely covered by black chromatophores over dorsal surfaces, dactylus brown.

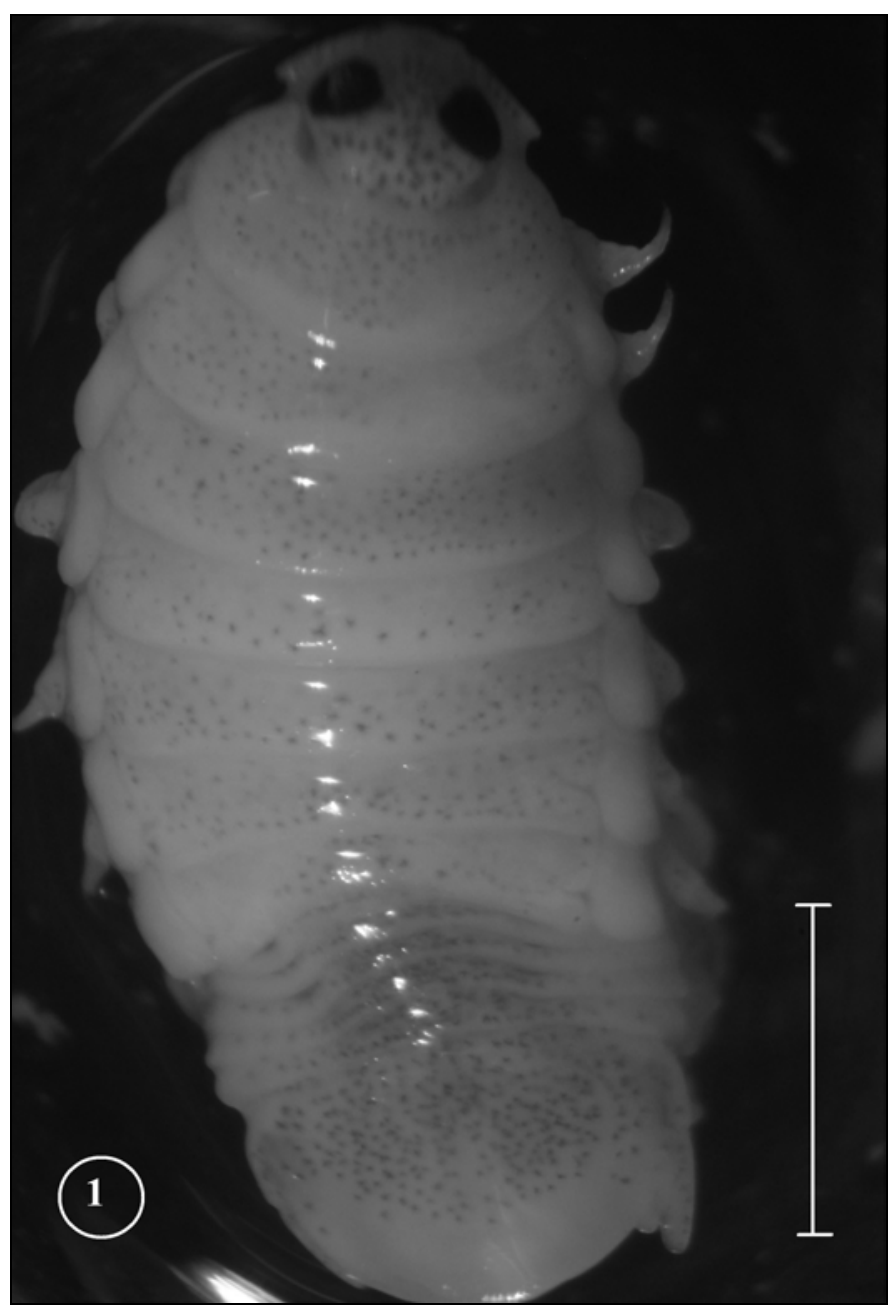

Figure 1: Female Mothocya epimerica (scale five mm). 


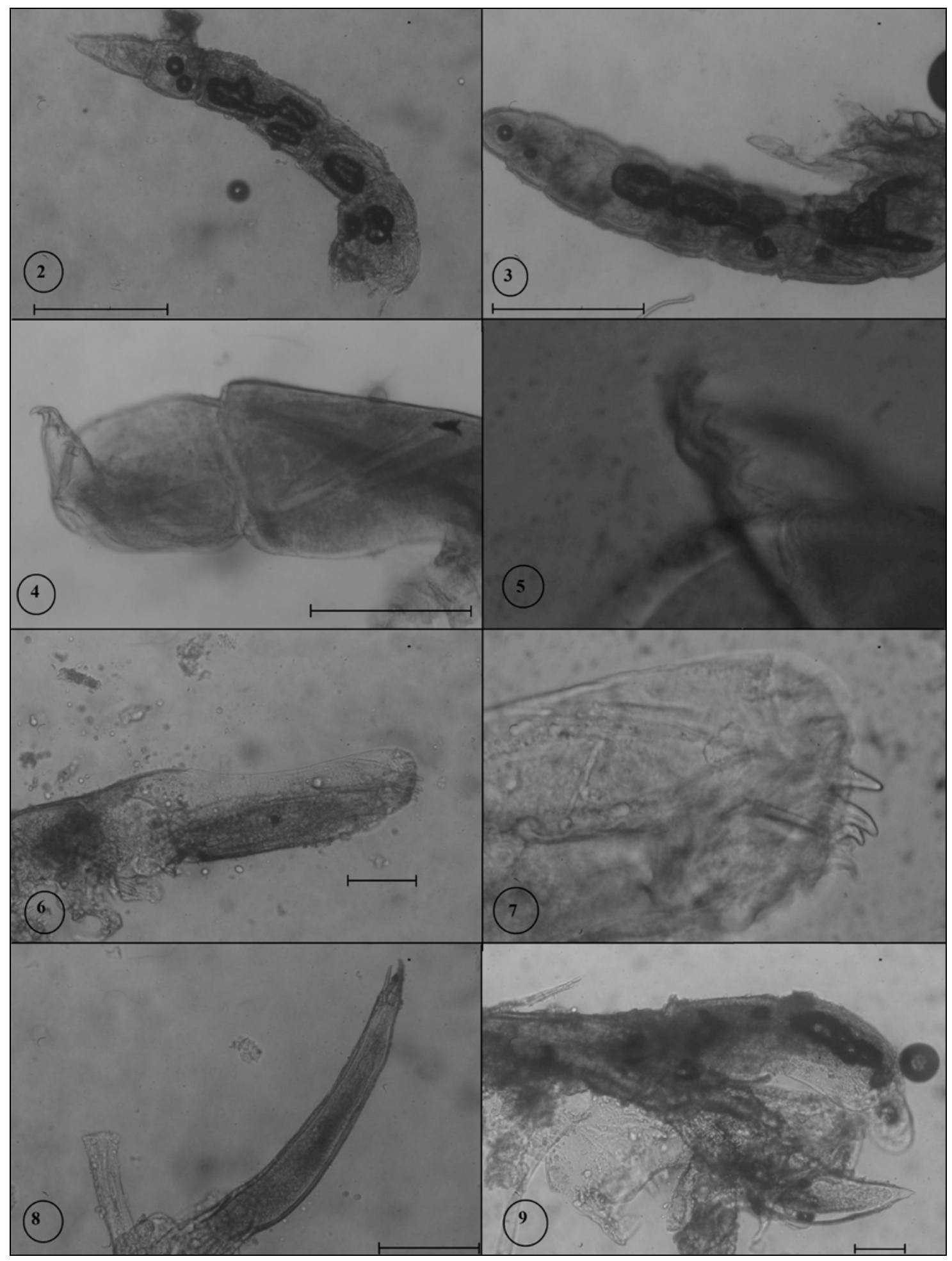

Figures 2-9: 2. Antenna (0.23 mm); 3. Antenna (0.26 mm); 4. Maxilliped (0.32 mm); 5. Maxilliped spines; 6. Maxilla ( $0.15 \mathrm{~mm})$; 7. Maxilla spines (two $\mathrm{mm})$; 8. Maxillule $(0.35 \mathrm{~mm})$; 9. Mandible $(0.11 \mathrm{~mm})$. 


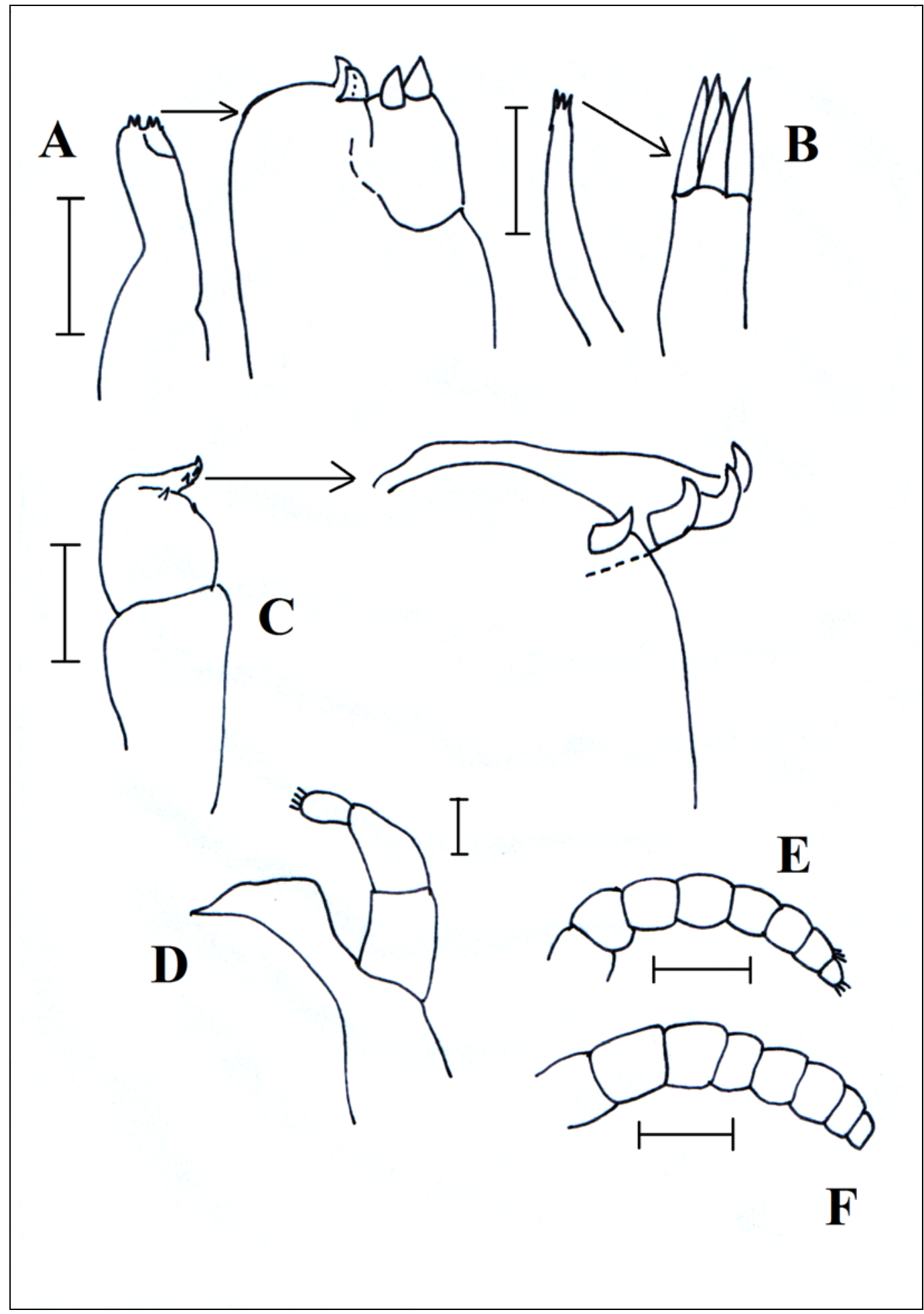

Figure 10: A: Maxilla (0.25 mm); B: Maxillule (0.35 mm); C: Maxilliped (0.40 mm); D: Mandible (0.11 mm); E: Antenna $(0.26 \mathrm{~mm})$; F: Antennule $(0.23 \mathrm{~mm})$. 


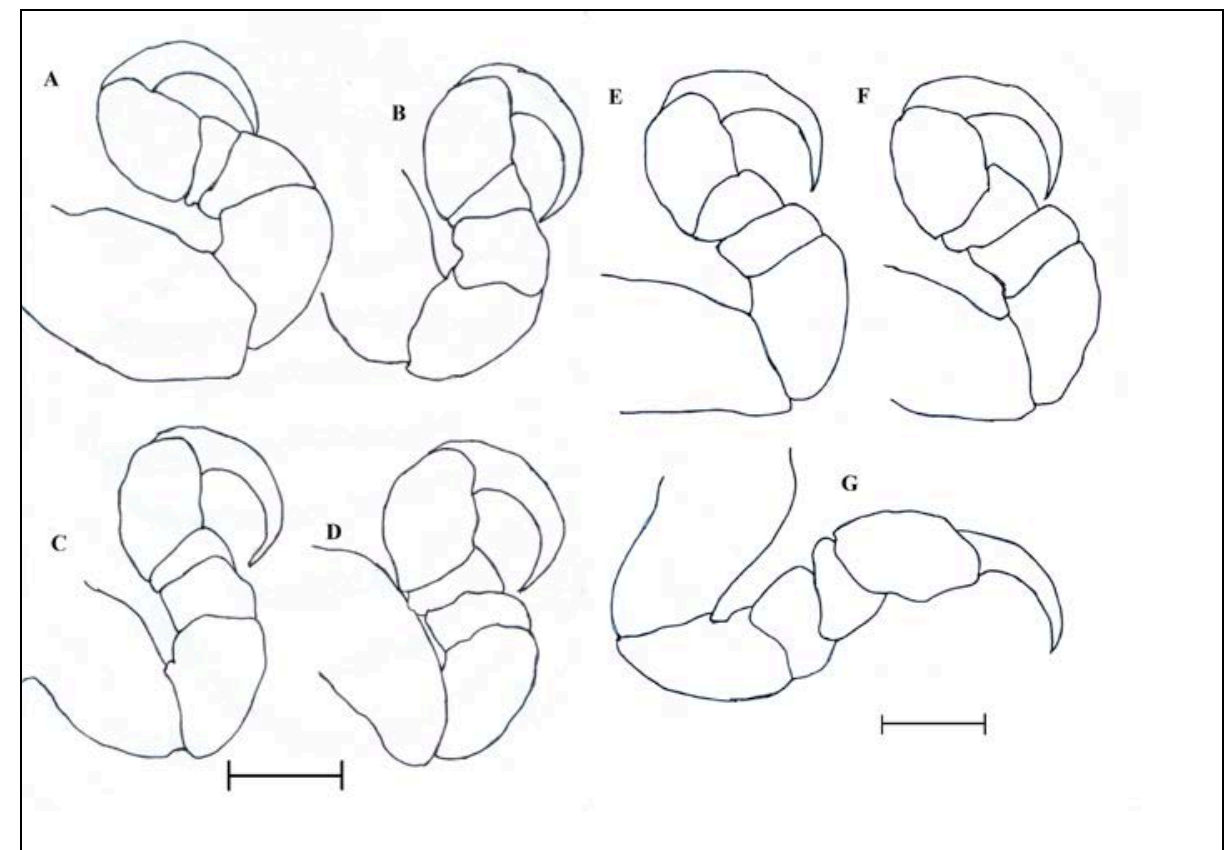

Figure 11: A. Pereopod I; B: II; C: III; D: IV; E: V; F: VI; G: VII (0.75 mm).

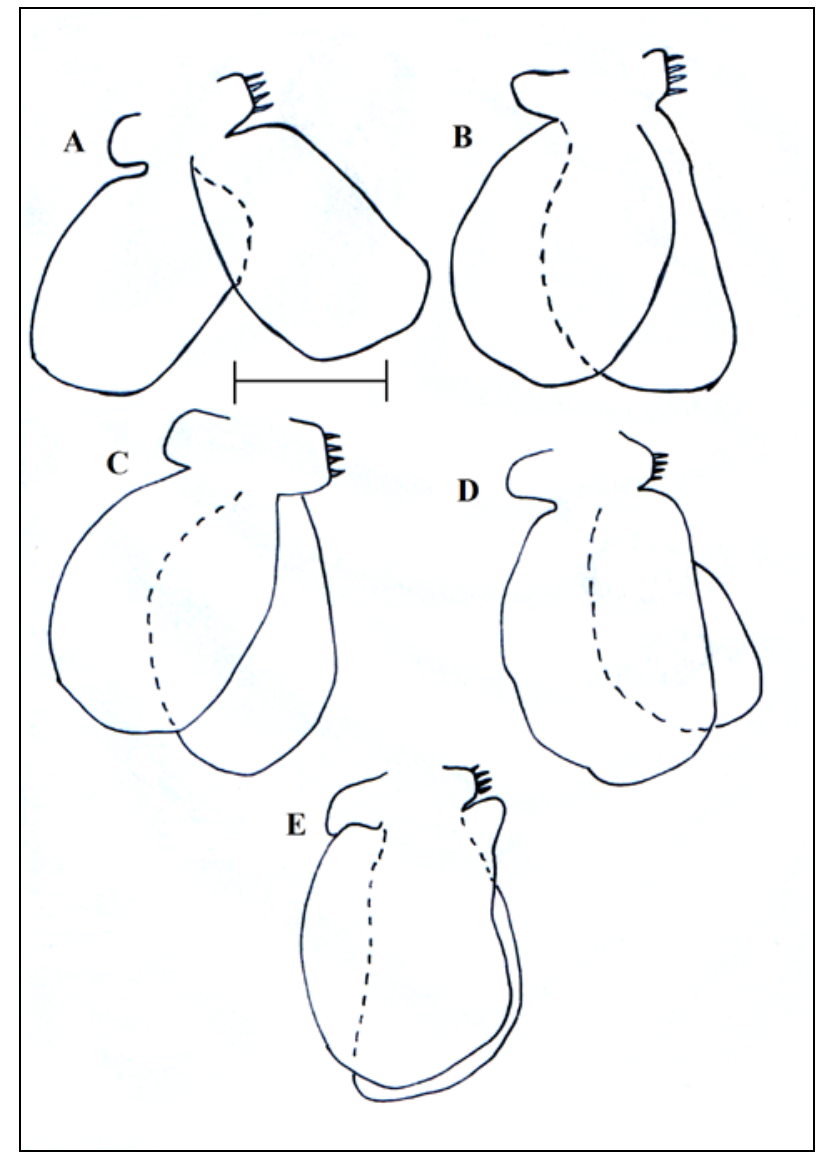

Figure 12: A: Pleopod I; B: II; C: III; D: IV; E: V. (one mm). 


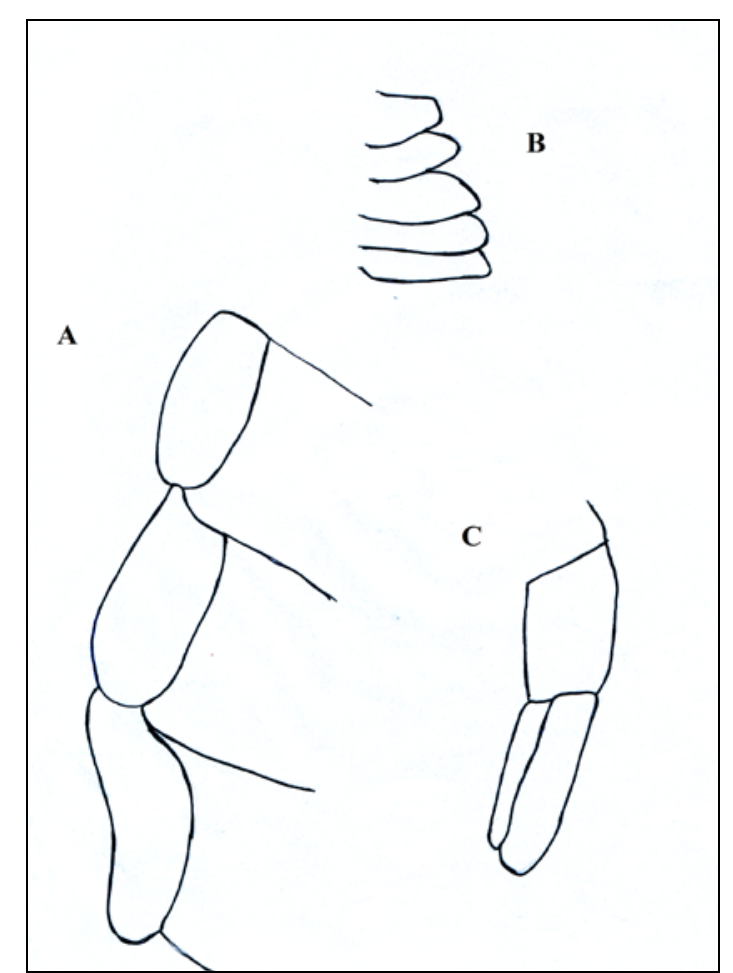

Figure 13: A: Coxae of left side; B: Pleonites, ventral view (left); C: Uropod.

\section{DISCUSSION}

Öktener and Sezgin (2000) recorded Mothocya epimerica for the first time in Turkey. They gave some morphological characters: antenna, antennule, pereopod and pleopod, but some characters were not explained in their publication.

After Trilles (1994) gave the distribution of Mothocya epimerica from the Mediterranean Sea, Black Sea, Adriatic, Atlantic, later, some records of it were published by Mariniello and Di Cave (1992), Bello et al. (1997), Charfi-Cheikhrouha et al. (2000), Öktener and Sezgin (2000), Leonardos and Trilles (2003), Ramdane et al. (2006), Trilles (2008), and Ramdane et al. (2009).

Mothocya epimerica is only associated with fishes belonging to the family Atherinidae. It was collected from Atherina hepsetus, Atherina boyeri (synonymies: Atherina rissoi, Atherina mochon) (Trilles, 1994).

Examination of the parasite specimens showed that they were $M$. epimerica according to the general drawings and descriptions given by Bruce (1986), Trilles (1968, 1976), Montalenti (1948). Their general body shapes, maxillule with four terminal spines, maxilla with two curved spines on medial and lateral lobes, mandible palp article three without setae, antennule and antenna with eight articles, maxilliped article three with four recurved spines, and pleopods two with four hooks agree with the drawings given by Bruce (1986), Trilles (1968, 1976), and Montalenti (1948).

\section{ACKNOWLEDGEMENT} literature.

We would thank Ceregato A., Mascolo R. and Maffei G. for obtaining scanned 


\section{REFERENCES}

1. Bello G., Vaglio A. and Piscitelli G., 1997 - The reproductive cycle of Mothocya epimerica a parasite of sand smelt Atherina boyeri, in the Lesina Laggon, Italy, Journal of Natural History, 3, 1055-1066.

2. Bruce N. L., 1986 - Revision of the isopod crustacean genus Mothocya Costa, in Hope, 1851 (Cymothoidae: Flabellifera), parasitic on marine fishes, Journal of Natural History, 20, 1089-1192.

3. Brusca R. C., 1981 - A monograph of the Isopoda Cymothoidae (Crustacea) of the eastern Pacific, Zoological Journal of the Linnean Society, 73, 117-199.

4. Charfi-Cheikhrouha F., Zghidi W., Oould Yarba L. and Trilles J. P., 2000 - Les Cymothoidae des côtes tunisiennes, Systematic Parasitology, 46, 146-150. (in French)

5. Froese R. and Pauly D., 2014 - FishBase. www.fishbase.org, version (accessed 06.03.2014).

6. Fricke R., Bilecenoğlu M. and Sarı H. M., 2007 - Annotated checklist of fish and lamprey species of Turkey, including a Red Listof threatened and declining species, Stuttgarter Beitr, 10, IV, 169.

7. İnnal D., Kırkım F. and Erk'akan F., 2007 - The parasitic isopods, Anilocra frontalis and Anilocra physodes in Antalya Gulf, Bulletin of the European Association Fish Pathologists, 27, 239-241.

8. Kayis S. and Er A., 2012 - Nerocila bivittata (Cymothidae, Isopoda) infestation on Syngnathid Fishes in the Eastern Black Sea, Bulletin of the European Association Fish Pathologists, 32, 4, 135-139.

9. Kırkım F., 1998 - Investigations on the systematics and ecology of the Aegean Sea Isopoda (Crustacea) fauna, Ege University, Institute of Science, PhD Dissertation, 238.

10. Leonardos I. and Trilles J., 2003 - Host - parasite relationships: occurrence and effect of the parasitic isopod Mothocya epimerica on sand smelt Arterina boyeri in the Mesolongi and Etolikon Lagoons (W. Greece), Diseases of Aquatic Organisms, 54, 243-251.

11. Mariniello L. and Di Cave D., 1992 - Crostacei parassiti di specie ittiche di interesse commerciale presenti nelle lagune costiere italiane, Parassitologia, 1, 92-93. (in Italian)

12. Monod T., 1931 - Crustaces de Syrie, in Gruvel A., Les etats de Syrie, Bibliographie Faunae Française, 3, 397-435. (in French)

13. Montalenti G., 1948 - Note sulla sistematica e la biologia di alcuni Cimotoidi del Golfo di Napoli (Emetha, Mothocya, Anilocra, Nerocila), Archivio di Oceanografia e Limnologia, 5, 25-81. (in Italian)

14. Öktener A. and Sezgin M., 2000 - Mothocya epimerica an isopod parasite in the branchial cavities of the Black Sea Silverfish Atherina boyeri, Turkish Journal of Marine Sciences, 6, 1, 23-29.

15. Öktener A. and Trilles J. P., 2004 - Report on the Cymothoids (Crustacea, Isopoda) collected from marine fishes in Turkey, Acta Adriatica, 45, 145-154.

16. Öktener A., Trilles J. P., Alaş A. and Solak K., 2009 - New hosts for species belonging to the genera Nerocila, Anilocra, Ceratothoa, Mothocya and Livoneca (Crustacea, Isopoda, Cymothoidae), Bulletin of the European Association Fish Pathologists, 29, 2, 51-57.

17. Ramdane Z., Bensouilah M. A. and Trilles J. P., 2006 - Comparaison entre les Cymothoidae (Crustacea, Isopoda) recoltes sur les poissons teleosteens des côtes Tunisiennes et Algériennes, Bulletin de Institut National Des Sciences et Technologies de La Mer, 11, 8, 29-33. (in French)

18. Ramdane Z., Bensouilah M. A. and Trilles J. P., 2009 - Étude des crustacés isopodes et copépodes ectoparasites de poissons marins algériens et marocains, Cybium, 33, 2 123-131. (in French)

19. Tokşen E., 1999 - Metazoon Gill Parasites of Culture Gilthead Sea Bream and Sea Bass in Aegean Sea Coast and Their Treatment, Ege University, Institute of Science, PhD Dissertation, 153.

20. Trilles J. P., 2008 - Marine isopods from the Senckenberg Research Institute (Crustacea, Isopoda: Cymothoidae, Aegidae, Corallanidae, Cirolanidae), Senckenbergiana biologica, 88, 1, 21-28.

21. Trilles J. P., 1968 - Recherches sur les Isopodes Cymothoidae des cotes françaises, These de Doctorat en Sciences, Montpellier, 1-307. (in French)

22. Trilles J. P., 1976 - Les Cymothoidae des côtes françaises, III, Les Lironecinae Schioedte et Meinert, 1884, Bulletin du Muséum national d'Histoire naturelle, Paris, 390, 272, 801-820. (in French)

23. Trilles J. P., 1994 - Les Cymothoidae (Crustacea, Isopoda) du monde (Prodrome pour une faune), Studia Marina, 21/22, 1-2, 1-288. (in French)

24. WoRMS Editorial Board, 2014 - World Register of Marine Species, available from http://www.marinespecies.org at VLIZ, accessed in 2014-01-26. 